How to cite this article:

Thinwiangthong, S., Eddy, C. M., \& Inprasitha, M. (2020). Mathematics teachers' abilities in developing formative assessment after the introduction of lesson study and open approach innovations. Malaysian Journal of Learning \& Instruction, 17 (1), 101-132. https://doi.org/10.32890/mjli2020.17.1.5

\title{
MATHEMATICS TEACHERS' ABILITIES IN DEVELOPING FORMATIVE ASSESSMENT AFTER THE INTRODUCTION OF LESSON STUDY AND OPEN APPROACH INNOVATIONS
}

\author{
${ }^{1}$ Sampan Thinwiangthong, ${ }^{2}$ Colleen M. Eddy \& \\ ${ }^{3}$ Maitree Inprasitha \\ ${ }^{1,3}$ Faculty of Education, Khon Kaen University, \\ Khon Kaen, Thailand \\ ${ }^{2}$ College of Education, \\ University of North Texas, Denton, Texas, USA \\ ${ }^{I}$ Corresponding author: sampan@kku.ac.th
}

Received: 28/3/2019 Revised: 9/12/2019 Accepted: 27/12/019 Published :31/1/2020

\begin{abstract}
Purpose - The main purpose of this study was to examine mathematics teachers' abilities in developing formative assessments when teaching algebraic reasoning after utilizing two innovations: lesson study and open approach.

Methodology - A single group quasi-experimental research design was employed in two mathematics classes in a school in Chaiyaphum province, Thailand. The target group was all the 11 mathematics teachers, who were pre-tested, then post-tested after the lesson study and open approach training. This was followed by their participation in setting up a lesson study group and conducting 10 lesson study cycles involving two research participants who were teaching two selected classes. The instruments were a questionnaire, the AssessToday rubric, interview protocols, 10 lesson plans, field notes, classroom observation video recordings, and students'
\end{abstract}


written work. The AssessToday rubric was the main instrument used to determine the ability level of the mathematics teachers in developing formative assessment in terms of seven components, namely learning targets, question quality, nature of questioning, selfevaluation, observation of student affect, instructional adjustment, and evidence of learning.

Results - The pre-test and post-test results showed an improvement in the mathematics teachers' understanding about formative assessment, the methods used in formative assessment, and how they could use the data from the formative assessment while they were implementing the two innovations. In addition, the AssessToday rubric showed that both mathematics teachers were progressing gradually from novice, apprentice to practitioner level in their abilities in developing formative assessment after the 10 cycles of innovation practices in all the seven components. The results imply that the mathematics teachers showed vast improvement in their abilities in developing formative assessment after they implemented the lesson study and open approach innovations in their teaching.

Significance-The results contribute significantly to knowledge about the usefulness of the lesson study and open approach innovations in enhancing mathematics teachers' abilities in developing formative assessment.

Keywords: AssessToday rubric; formative assessment abilities; lesson study; open approach; mathematics teachers.

\section{INTRODUCTION}

Classroom assessment is important because it enables mathematics teachers to make informed decisions about further lessons and consequently leads to instruction that adequately fits their students' needs and possibilities (Veldhuis, 2015). According to Black, Harrison, Lee, Marshall, and William (2004), any kind of assessment that is designed to promote students' learning is considered as assessment for learning. Black et al. (2004) further clarified that an assessment activity can aid students' learning because it offers information to mathematics teachers that enables them to adjust the teaching and learning activities in which they are involved. Hence, they defined such assessment as formative assessment because the 
evidence is used to adapt the teaching work to meet learning needs. Heritage (2007) indicated that there are three types of formative assessment, namely, on-the-fly assessment, which takes place while teaching; planned-for instruction, which is planned before teaching to support students' learning; and curriculum-embedded assessment, which encompasses two parts: teacher and curriculum developer, which provides feedback on learning order, as well as in-class learning assessment. In other words, assessment is considered as one of the essential components of education (Centre for Educational Research and Innovation, 2008). As a result, the Thailand Ministry of Education (2008) urged teachers to assess their students' progress using various methods that are not only relevant to the students' developmental levels but also suitable for that particular subject requirement.

Lesson study (LS), a long-established practice of lesson preparation which originated in Japan, has been in existence for over 130 years (Tall, 2008). Lewis (2002) defined LS as a teacher-led instructional improvement cycle in which teachers work together to convey student learning targets, design a lesson, teach and/or observe the lesson, reflect on the collected evidence, go through the lesson for improvement, and re-teach the reviewed lesson. In short, LS allows teachers to collaborate to design, test, and improve lesson sequences that are likely to improve learning and be useable by other teachers (Tall, 2008). Teachers thus have a means for planning, observing, and conferring with others (Meyer \& Wilkerson, 2011). In recent years, LS has gained substantial impetus around the educational world, particularly in the mathematics education community. This is because LS involves writing a plan that fits in with the overall development of a syllabus, stipulating the key objectives of the lessons and the comprehensive development of the lesson arrangement, including an expectation of the diverse ideas that students may offer so that mathematics teachers can take them into account during the lesson itself (Tall, 2008). According to Hart, Alston, and Murata (2011), LS is a professional learning model based on collaboration to support mathematics teachers' learning about content, curriculum and student thinking, as well as to facilitate greater reflection and more focus on conversations than traditional types of professional development.

The open approach (OA) also originated in Japan, and encourages mathematics teachers to foster the best possible learning environment 
in any type of educational activities. Nohda (2000) emphasized that the ideas of OA are aimed at allowing students to learn mathematics in response to their own mathematical power, accompanied with a certain degree of self-determination in their learning, which can increase the quality of their processes and results in mathematics.

In Thai schools, students are given inadequate exposure to real-life learning and hands-on experiences. Therefore, Thai mathematics classrooms are usually structured, depend on rote memorization skills and have minimal class discussion (Kaur, Awang Hashim, \& Noman, 2014). In this context, the researchers would like to explore how the mechanisms of learning and development relate to the integration of LS and OA into the mathematics subject teaching activities, and thus how the teachers' abilities in developing formative assessment can be optimized. In other words, LS is a tool to improve the teaching approach while OA is a teaching approach and an aspect of LS (Inprasitha, 2011). The LS concept in this study was adopted from Inprasitha (2011) and includes three important steps, namely collaboratively plan, do, and see. OA refers to a teaching approach that is focused on dealing with an open-ended problem, which is expected to improve the classroom instruction effectively (Becker \& Shimada, 1997). With the combination of these two innovations, LS and OA, mathematics teachers have more opportunity to assess students' learning and utilize the results derived from the assessment to improve classroom instruction.

The combination of the two innovations, LS and OA has been previously employed in a collaborative research project between the University of North Texas, United States of America and the Center for Research in Mathematics Education (CRME), Khon Kaen University, Thailand, by using the AssessToday rubric to measure mathematics teachers' abilities to develop formative assessment in terms of advancing the teaching and learning of algebraic reasoning. The AssessToday rubric is an immediate assessment tool created by Eddy and Harrell (2013), which can be used to measure mathematics teachers' abilities to develop formative assessment in the context of instruction provided by LS and OA (Eddy \& Inprasitha, 2012).

\section{CONCEPTUAL FRAMEWORK}

Based on past research evidence, formative assessment has the potential to raise students' achievements if it is used correctly and 
consistently (Black et al., 2004; Black \& William, 1998; Bloom, 1984; Leahy, Lyon, Thompson, \& William, 2005). This is further supported by Eddy and Harrell (2013), who stated that formative assessment enables students to take risks and try new things in the mathematics classroom without feeling any threat or fear, or having any interruption from their teachers (Eddy \& Harrell, 2013). In addition, many researchers (Cizek, 2001; Gallagher, 2010; William, 2010) have discovered that there is a need to support mathematics teachers in their use and development of formative assessment practices because of a gap in the current development of formative assessment.

According to Tachibana (2007), assessments for learning allow mathematics teachers and students to see their learning paths in a positive way, and reflect the students' learning as well as the teachers' instruction. Therefore, mathematics teachers need to have knowledge about providing formative assessments and the ability to assess students' learning and their own classroom instruction (Fernandez, Cannon, \& Chokshi, 2003). Along this line of reasoning, Eddy and Harrell (2013) developed the AssessToday rubric as an assessment tool for classroom observation in order to understand students' learning processes and improve classroom instruction, whereby mathematics teachers implement innovations to constantly develop their teaching skills. The AssessToday rubric was developed with two guiding principles, namely feedback and instructional correctives. Feedback includes questioning, self-evaluation and observation of student affect, whereas instructional correctives include instructional adjustments and evidence of learning. According to Harlen (2007), a mathematics teacher's content knowledge is reflected in the questions they ask, the classroom discussions that ensue, and comments teachers make regarding student artifacts. Heritage (2010) stated that an effective formative assessment requires mathematics teachers to have the necessary depth of content knowledge while observers who are using AssessToday need to identify if teachers are effectively meeting these requirements.

LS is a continuing teacher-directed professional learning method, involving a group of mathematics teachers who have to plan, conduct, and reflect on research lessons collaboratively and systematically (Tan, Lim, \& Chew, 2017). In this study, the three steps of LS (Inprasitha, 2011), namely collaboratively plan, do, and 
see, were utilized. The research lesson refers to the lesson taught by two mathematics teachers to the two selected classes, based on the lesson plan developed by the target group, consisting of all the mathematics teachers who were teaching in the research school. The target group observed and data was collected about the students' learning and teachers' abilities in developing formative assessment during the research lesson. The teachers reflected based on the collected data after each research lesson.

The OA is an approach that mathematics teachers have conventionally been using to highlight mathematical perspectives in their research and practice (Nohda, 2000). Within this approach, the mathematics teachers assign their students with so-called open problems, where the goal is not given precisely. Therefore, students need to solve an open problem using numerous methods to investigate the problem mathematically, exploring numerous methods to the given problem, and posing various innovative solutions (Sambová \& Tichá, 2016). The four steps of OA (Eddy \& Inprasitha, 2012), namely posing openended problems, students' self-learning, whole class discussion and comparison, and summing up by connecting students' mathematical ideas, were utilized in this study.

LS and OA together were integrated and adapted into the two classes for a period of 15 weeks. This allowed both mathematics teachers (research participants) more opportunity to assess the students' learning and utilize the results derived from the assessment to improve their teaching. The target group consisted of all 11 mathematics teachers in the research school, who would meet every Tuesday to plan the lesson collaboratively. This was followed by the second step of LS, collaboratively do. At the second step, the two research participants integrated the four steps of OA into their teaching. By the end of each research lesson, the target group would meet again in the third step to reflect on what they had seen during the lesson, to revise and re-teach for improvement.

The AssessToday rubric (Eddy \& Harrell, 2013) evaluates how research participants utilize their abilities in developing formative assessment in a single research lesson. This rubric utilizes seven components of abilities in developing formative assessment: writing learning targets, using quality questions, nature of questioning, selfevaluation, observation of student affect, instructional adjustment, 
and evidence of learning. Each component is assessed according to the four proficiency ranks that are constructed on mastery (Eddy, Harrell, \& Heitz, 2017). The learning target component is important as mathematics teachers have to communicate the learning objectives of the research lesson in order to get the students to understand the direction of learning. There are four actions used to establish the learning targets: firstly, the teacher identifies the learning objectives; secondly, the teacher writes down the learning objectives so that students can understand them; thirdly, the students note down the learning objectives; and, finally, the teacher revises the learning objectives during the research lesson. The learning target is a key component of formative assessment because it is a driving force in implementing learning activities and motivating students to learn effectively. If mathematics teachers are going to use formative assessments to assist their students in the learning process, they must have a target in mind and know how they are going to achieve the target. Besides, students can assess themselves in their learning progression if mathematics teachers provide clear objectives. On top of that, learning targets also offer a context for responses that can be achieved by questioning and student behaviour observation (Heitz, 2013). The importance of connecting classroom feedback to the established learning target has been emphasized by Brookhart, Moss, and Long (2008).

The quality of classroom questioning is the second key component of mathematics teachers' abilities in developing formative assessment because good quality teachers' questions can encourage students to evoke previous knowledge and widen their mathematical thinking with support (Chin, 2006). As a result, the questioning construct is divided into two components in the Assess Today rubric, namely question quality and nature of questioning. Question quality encompasses three indicators, namely open-ended questions, Bloom's hierarchy of cognitive learning levels and prior knowledge, while the nature of questioning consists of two indicators, namely wait time and follow-up questions (Eddy, Harrell, \& Heitz, 2017).

Self-evaluation is a method used by students to reflect on their work quality by comparing it with the identified learning target, making adjustments if required (Andrade, 2010). This self-evaluation component consists of three key indicators, namely self-evaluation strategies during the research lesson, clearly defined strategies associated with the learning target, and students' comprehension 
of how to evaluate their learning and use the strategies to evaluate their learning. Students should exhibit persistent practice of selfevaluation strategies throughout the research lesson (Eddy \& Harrell, 2013).

Observation of student affect includes students' attitudes, interests, values, and disposition, all of which play important roles in formative assessment (Popham, 2008). If mathematics teachers interpret the affective signals of their students effectively, achievement will increase and opportunities for improvement will be maximized. Therefore, Stiggins (2010) highlighted that the successful use of formative assessment is not merely quality assessment and appropriate instructional adjustment, but also includes careful management of students' emotional state. According to Eddy and Harrell (2013), the student affect component consists of four principal indicators that can be observed in a mathematics class, namely student behaviour, teacher behaviour, teacher focus, and student interactions. According to Popham (2008), student behaviour is defined as the extent of student responses to teachers' questioning, the classroom engagement level, signs of critical thinking, and demonstration of confidence. Bell and Cowie (2001) referred to teachers' behaviour as their sensitivity to students' feelings, body language, facial expressions, and assignments. Shute (2008) clarified that mathematics teachers' focus is not only implementing a student-centred approach but also demonstrating a content and sensitivity balance to the students' affective needs. Leahy et al. (2005) defined student interactions as all the possible student interactions, including student-to-student, student-to-group and student-to-teacher interactions. According to Shepard (2000), mathematics teachers should vigorously boost student interaction and risk taking.

Instructional adjustments of abilities in developing formative assessment is to inform mathematics teachers to adjust their instruction to assist understanding as teachers have to practice a diverse teaching strategy (Popham, 2008). For example, if students are engaged in the learning and there is evidence of their understanding the content, the current strategy is reinforced and the mathematics teacher can continue teaching with the current plan. Instructional adjustments include the four primary indicators, namely instructional strategy, instructional timing, instructional audience, and grouping strategies (Heitz, 2013). Black and William (2009) defined instructional strategies as numerous strategies 
accessible for mathematics teachers to gather students' learning feedback. Instructional timing refers to the timing of the adjustment, which is particularly vital in the instructive setting. Subsequently, Guskey (2007) highlighted the importance of mathematics teachers gathering students' evidence in order to decide the best period to endorse the adjustment. The instructional audience is defined as the cluster of students who need the teacher's explanation, which may be an individual, a small group, or the entire class. Grouping strategies refer to a predominant strategy that is used with regards the students' grouping arrangements. The idea and purpose of grouping should be an essential consideration when employing formative assessment. Therefore, mathematics teachers should deliberately create groups to take full advantage of and lessen the disadvantages of group dynamics (Black \& William, 2009).

Evidence of learning requires mathematics teachers to gather quality feedback including all-student responses, individual responses, and student artifacts. However, Heritage (2010) suggests four criteria when teachers are gathering evidence. Firstly, the evidence should show that the student's learning is affiliated with the learning target. Secondly, mathematics teachers should gather sufficient evidence before they make appropriate adjustments. Thirdly, mathematics teachers should collect a wide range of evidence including students' understanding or skill levels so that the evidence can account for all students. Finally, the evidence should be gathered using more than one strategy to offer teachers sufficient evidence that students have accomplished the anticipated learning target.

The OA approach starts with having students engage in open-ended problems which are formulated to have multiple correct answers "incomplete" or "open-ended". Mathematical activities generated by open ended problems are rich so that mathematics teachers can evaluate students' higher order thinking skills as a learning target. Besides, an open-ended problem is a good start for creating the first study lesson for the learning target in the LS approach. Questioning is one of the most basic and effective methods used by teachers to gain information, stimulate participation and challengethinking (Korkmaz, 2009). The quality of mathematics teacher's questions can influence the degree to which students are able to recall prior knowledge and extend their thinking through scaffolding (Chin, 2006). The nature of questioning such as probing is another questioning strategy that encourages higher order thinking. Self-evaluation is a process 
whereby students become self-regulated learners to answer those critical questions during the instruction time. Much can be learned from students by observing their body language, facial expression and quality of work. Thus, observation of student affect plays a key role in formative assessment. Formative assessment can be effective in the classroom to inform mathematics teachers about instructional adjustments they need to make to facilitate better understanding. Finally, evidence of learning should be gathered when students have achieved the desired learning target.

The seven components of mathematics teachers' abilities described above were measured using the AssessToday rubric. The researchers adapted Eddy and Harrel's (2013) AssessToday rubric, coupled with Inprasitha's (2011) concepts of LS and OA (Eddy \& Inprasitha, 2012), and finally supported by the previous research findings of Thinwiangthong, Suttiamporn, Pattanajak, and Inprasitha (2017) to design this study.

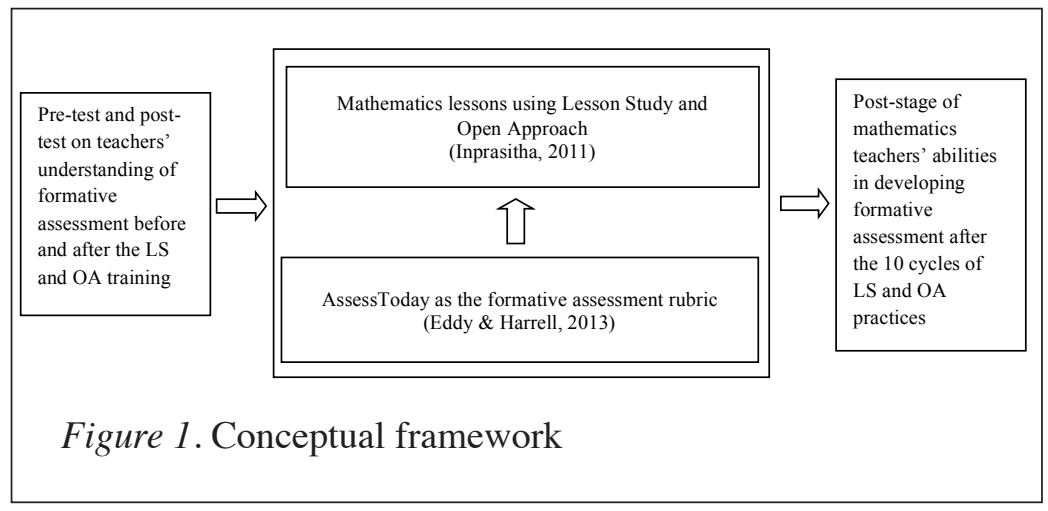

Figure 1 shows the conceptual framework. At the pre-stage of the study, all the 11 mathematics teachers from the research school attended the LS and OA workshop for two days. They were trained and learned how to implement the LS, OA and AssessToday components. The pre-test and post-test were conducted before and after the training respectively. After the workshop, two out of the 11 mathematics teachers conducted 10 mathematics lessons, and their abilities in developing formative assessment were measured using the AssessToday rubric. The researchers identified the abilities of mathematics teachers in developing formative assessment according to an ascending order, from novice, through apprentice and practitioner to master, as indicated in Table 1, based on their observation data. 
Finally, at the post stage, after the cycle of 10 research lessons, the impact of LS and OA on the mathematics teachers' abilities in developing formative assessment was evaluated.

\section{Table 1}

\section{Details of the AssessToday rubric}

\begin{tabular}{|c|c|c|c|c|}
\hline Components & Novice & Apprentice & Practitioner & Master \\
\hline $\begin{array}{c}\text { 1. Learning } \\
\text { target }\end{array}$ & $\begin{array}{l}\text { Teacher does } \\
\text { not write } \\
\text { any learning } \\
\text { objectives in } \\
\text { the lesson plan } \\
\text { or they do but } \\
\text { do not put } \\
\text { the learning } \\
\text { objectives into } \\
\text { practice in } \\
\text { class. }\end{array}$ & $\begin{array}{l}\text { 1) Teacher } \\
\text { writes learning } \\
\text { objectives in the } \\
\text { lesson plan. } \\
\text { 2) Teacher } \\
\text { compares } \\
\text { students' ideas } \\
\text { acquisition with } \\
\text { the designated } \\
\text { learning } \\
\text { objectives. }\end{array}$ & $\begin{array}{l}\text { 1) Teacher } \\
\text { writes learning } \\
\text { objectives in the } \\
\text { lesson plan. } \\
\text { 2) Teacher } \\
\text { compares } \\
\text { students' ideas } \\
\text { acquisition with } \\
\text { the designated } \\
\text { learning } \\
\text { objectives. } \\
\text { 3) Teacher leads } \\
\text { the discussion } \\
\text { for students, } \\
\text { summarizes, and } \\
\text { interconnects all } \\
\text { the ideas until } \\
\text { the learning } \\
\text { objectives are } \\
\text { achieved. }\end{array}$ & $\begin{array}{l}\text { 1) Teacher } \\
\text { writes learning } \\
\text { objectives in } \\
\text { the lesson plan } \\
\text { 2) Teacher } \\
\text { compares } \\
\text { students' ideas } \\
\text { acquisition } \\
\text { with the } \\
\text { designated } \\
\text { learning } \\
\text { objectives. } \\
\text { 3) Teacher } \\
\text { leads the } \\
\text { discussion } \\
\text { for students, } \\
\text { summarizes, } \\
\text { and } \\
\text { interconnects } \\
\text { all the ideas } \\
\text { until the } \\
\text { learning } \\
\text { objectives are } \\
\text { achieved. } \\
\text { 4) Students } \\
\text { indicate } \\
\text { through } \\
\text { writing which } \\
\text { designated } \\
\text { learning } \\
\text { objectives they } \\
\text { have met. }\end{array}$ \\
\hline $\begin{array}{c}\text { 2. Question } \\
\text { quality }\end{array}$ & $\begin{array}{l}\text { Teacher does } \\
\text { not use quality } \\
\text { questions in } \\
\text { class. }\end{array}$ & $\begin{array}{l}\text { Teacher rarely } \\
\text { uses quality } \\
\text { questions for } \\
\text { 1) checking } \\
\text { students' prior } \\
\text { knowledge and } \\
\text { understanding; } \\
\text { 2) encouraging } \\
\text { students' } \\
\text { problem-solving. }\end{array}$ & $\begin{array}{l}\text { Teacher generally } \\
\text { uses a variety of } \\
\text { questions for } \\
\text { 1) checking } \\
\text { students' prior } \\
\text { knowledge and } \\
\text { understanding; } \\
\text { 2) encouraging } \\
\text { students' } \\
\text { problem-solving; }\end{array}$ & $\begin{array}{l}\text { Teacher } \\
\text { properly uses } \\
\text { a variety of } \\
\text { questions for } \\
\text { 1) checking } \\
\text { students' prior } \\
\text { knowledge and } \\
\text { understanding; } \\
\text { 2) encouraging } \\
\text { students' } \\
\text { problem- } \\
\text { solving; }\end{array}$ \\
\hline
\end{tabular}




\begin{tabular}{|c|c|c|c|c|}
\hline Components & Novice & Apprentice & Practitioner & Master \\
\hline & & & $\begin{array}{l}\text { 3) providing } \\
\text { students with } \\
\text { opportunities } \\
\text { to explain and } \\
\text { compare the } \\
\text { ideas as well as } \\
\text { summarize them. }\end{array}$ & $\begin{array}{l}\text { 3) providing } \\
\text { students with } \\
\text { opportunities } \\
\text { to explain and } \\
\text { compare the } \\
\text { ideas as well } \\
\text { as summarize } \\
\text { them; } \\
\text { 4) challenging } \\
\text { students to } \\
\text { think creatively } \\
\text { or pose new } \\
\text { problems. }\end{array}$ \\
\hline $\begin{array}{l}\text { 3. Nature of } \\
\text { question- } \\
\text { ing }\end{array}$ & $\begin{array}{l}\text { 1) Teacher is } \\
\text { not patient } \\
\text { enough to wait } \\
\text { for students' } \\
\text { answers, or } \\
\text { 2) Teacher does } \\
\text { not ask proper } \\
\text { questions to } \\
\text { elicit more } \\
\text { information } \\
\text { from students' } \\
\text { answers in order } \\
\text { to diagnose the } \\
\text { problems and } \\
\text { expand learning. }\end{array}$ & $\begin{array}{l}\text { 1) Teacher is } \\
\text { patient when } \\
\text { waiting for } \\
\text { students' answers. } \\
\text { 2) Teacher asks } \\
\text { proper questions } \\
\text { to elicit more } \\
\text { information } \\
\text { from students' } \\
\text { answers in order } \\
\text { to diagnose the } \\
\text { problems and } \\
\text { expand learning. }\end{array}$ & $\begin{array}{l}\text { 1) Teacher is } \\
\text { consistently } \\
\text { patient when } \\
\text { waiting for } \\
\text { students' answers. } \\
\text { 2) Teacher asks } \\
\text { proper questions } \\
\text { following } \\
\text { students' answers } \\
\text { in order to } \\
\text { diagnose the } \\
\text { problems and } \\
\text { expand learning. }\end{array}$ & $\begin{array}{l}\text { 1) Teacher is } \\
\text { consistently } \\
\text { patient when } \\
\text { waiting for } \\
\text { students' } \\
\text { answers. } \\
\text { 2) Teacher } \\
\text { consistently asks } \\
\text { proper questions } \\
\text { following } \\
\text { students' } \\
\text { answers in order } \\
\text { to diagnose the } \\
\text { problems and } \\
\text { expand learning. }\end{array}$ \\
\hline
\end{tabular}

4. Selfevaluation

Teacher does not
tell or encourage
students to do
self-assessment
or check
their thinking
process.

Teacher tells and encourages students to do self-assessment and check their thinking process. However, it is not clear how students improve their learning.
Teacher tells and encourages students to do selfassessment, check their thinking process and improve their learning consistently.
Students do selfassessment, examine their own critical thinking skills and improve their learning consistently without guidance from teacher. 


\begin{tabular}{|c|c|c|c|c|}
\hline Components & Novice & Apprentice & Practitioner & Master \\
\hline $\begin{array}{l}\text { 5. Observa- } \\
\text { tion of stu- } \\
\text { dent affect }\end{array}$ & $\begin{array}{l}\text { 1) Students } \\
\text { do not show } \\
\text { active learning } \\
\text { behaviours (e.g., } \\
\text { giving meaning- } \\
\text { ful answers, } \\
\text { thinking thor- } \\
\text { oughly, showing } \\
\text { self-confidence). } \\
\text { 2) Teacher } \\
\text { cannot perceive } \\
\text { students' feel- } \\
\text { ings. }\end{array}$ & $\begin{array}{l}\text { 1) Students show } \\
\text { active learning } \\
\text { behaviours (e.g., } \\
\text { giving meaningful } \\
\text { answers, thinking } \\
\text { thoroughly, } \\
\text { showing self- } \\
\text { confidence). } \\
\text { 2) Teacher can } \\
\text { perceive students' } \\
\text { feelings. }\end{array}$ & $\begin{array}{l}\text { 1) Students show } \\
\text { active learning } \\
\text { behaviours (e.g., } \\
\text { giving meaningful } \\
\text { answers, thinking } \\
\text { thoroughly, } \\
\text { showing self- } \\
\text { confidence). } \\
\text { 2) Teacher can } \\
\text { perceive students' } \\
\text { feelings. } \\
\text { 3) Teacher adjusts } \\
\text { their teaching } \\
\text { methods to } \\
\text { balance lesson } \\
\text { content with } \\
\text { students' feelings. }\end{array}$ & $\begin{array}{l}\text { 1) Students } \\
\text { show active } \\
\text { learning } \\
\text { behaviours } \\
\text { (e.g., giving } \\
\text { meaningful } \\
\text { answers, } \\
\text { thinking } \\
\text { thoroughly, } \\
\text { showing self- } \\
\text { confidence). } \\
\text { 2) Teacher } \\
\text { can perceive } \\
\text { students' } \\
\text { feelings. } \\
\text { 3) Teacher } \\
\text { adjusts their } \\
\text { teaching } \\
\text { methods to } \\
\text { balance lesson } \\
\text { content with } \\
\text { students' } \\
\text { feelings. } \\
\text { 4) Teacher } \\
\text { provides } \\
\text { opportunities } \\
\text { to students who } \\
\text { have divergent } \\
\text { ideas in order } \\
\text { to present to the } \\
\text { class. }\end{array}$ \\
\hline $\begin{array}{l}\text { 6. Instruc- } \\
\text { tional adjust- } \\
\text { ment }\end{array}$ & $\begin{array}{l}\text { 1) Teacher does } \\
\text { not adapt their } \\
\text { teaching style in } \\
\text { accordance with } \\
\text { the teaching } \\
\text { assessment. } \\
\text { 2) Teacher does } \\
\text { not respond } \\
\text { to students at } \\
\text { the appropriate } \\
\text { time. }\end{array}$ & $\begin{array}{l}\text { 1) Teacher makes } \\
\text { slight adjustments } \\
\text { to their teaching in } \\
\text { accordance with } \\
\text { the assessment. } \\
\text { 2) Teacher } \\
\text { responds to } \\
\text { students at the } \\
\text { appropriate time. }\end{array}$ & $\begin{array}{l}\text { 1) Teacher } \\
\text { properly adjusts } \\
\text { their teaching } \\
\text { in accordance } \\
\text { with the teaching } \\
\text { assessment. } \\
\text { 2) Teacher } \\
\text { properly responds } \\
\text { to students at the } \\
\text { appropriate time. } \\
\text { 3) Teacher spends } \\
\text { time interacting } \\
\text { with students } \\
\text { (individuals, pairs, } \\
\text { groups, whole } \\
\text { class) properly. }\end{array}$ & $\begin{array}{l}\text { 1) Teacher } \\
\text { properly adjusts } \\
\text { their teaching in } \\
\text { accordance with } \\
\text { the teaching } \\
\text { assessment. } \\
\text { 2) Teacher } \\
\text { properly and } \\
\text { consistently } \\
\text { responds to } \\
\text { students at the } \\
\text { appropriate } \\
\text { time. } \\
\text { 3) Teacher } \\
\text { spends time } \\
\text { interacting } \\
\text { with students } \\
\text { (individuals, } \\
\text { pairs, groups, } \\
\text { whole class) } \\
\text { properly and } \\
\text { consistently. } \\
\text { 4) Teacher uses } \\
\text { group work } \\
\text { in association } \\
\text { with lesson } \\
\text { objectives. }\end{array}$ \\
\hline
\end{tabular}




\begin{tabular}{|c|c|c|c|c|}
\hline Components & Novice & Apprentice & Practitioner & Master \\
\hline $\begin{array}{l}\text { 7. Evidence } \\
\text { of Learnin }\end{array}$ & $\begin{array}{l}\text { 1) Teacher has } \\
\text { little learning } \\
\text { evidence } \\
\text { from students } \\
(0-24 \%) \text {, such } \\
\text { as problem- } \\
\text { solving notes, } \\
\text { learning } \\
\text { summary, } \\
\text { inventions, etc. } \\
\text { 2) Teacher } \\
\text { uses learning } \\
\text { ideas derived } \\
\text { from learning } \\
\text { evidence } \\
\text { to confirm } \\
\text { students' } \\
\text { comprehension } \\
\text { in ways that } \\
\text { do not meet } \\
\text { the learning } \\
\text { objectives. }\end{array}$ & $\begin{array}{l}\text { 1) Teacher has } \\
\text { some learning } \\
\text { evidence from } \\
\text { students ( } 25- \\
49 \% \text { ), such as } \\
\text { problem-solving } \\
\text { notes, learning } \\
\text { summary, } \\
\text { inventions, etc. } \\
\text { 2) Teacher } \\
\text { uses learning } \\
\text { ideas derived } \\
\text { from learning } \\
\text { evidence to } \\
\text { confirm students' } \\
\text { comprehension } \\
\text { in some ways } \\
\text { that meet } \\
\text { the learning } \\
\text { objectives. }\end{array}$ & $\begin{array}{l}\text { 1) Teacher has } \\
\text { a lot of learning } \\
\text { evidence from } \\
\text { students (50- } \\
74 \% \text { ), such as } \\
\text { problem-solving } \\
\text { notes, learning } \\
\text { summary, } \\
\text { inventions, etc. } \\
\text { 2) Teacher uses } \\
\text { all learning } \\
\text { ideas derived } \\
\text { from learning } \\
\text { evidence to } \\
\text { confirm students' } \\
\text { comprehension } \\
\text { and to summarize } \\
\text { all connections } \\
\text { towards } \\
\text { achieving } \\
\text { the learning } \\
\text { objectives. }\end{array}$ & $\begin{array}{l}\text { 1) Teacher } \\
\text { has learning } \\
\text { evidence from } \\
\text { all or almost all } \\
\text { students ( } 75- \\
\text { 100\%), such } \\
\text { as problem- } \\
\text { solving notes, } \\
\text { learning } \\
\text { summary, } \\
\text { inventions, etc. } \\
\text { 2) Teacher uses } \\
\text { all learning } \\
\text { ideas derived } \\
\text { from learning } \\
\text { evidence } \\
\text { to confirm } \\
\text { students' } \\
\text { comprehension } \\
\text { and to } \\
\text { summarize all } \\
\text { connections } \\
\text { towards } \\
\text { achieving } \\
\text { the learning } \\
\text { objective; } \\
\text { students } \\
\text { also write a } \\
\text { summary of } \\
\text { what they have } \\
\text { learned. }\end{array}$ \\
\hline
\end{tabular}

\section{METHOD}

\section{Research Design and Participants}

A single group quasi-experimental research design was employed in this study. This research design was particularly suitable for addressing assessment questions about the impact of LS and OA innovations because it emphasized the use of comparative data as the context for interpreting results (Srikoon, Bunterm, Nethanomsak, \& Tang, 2017). The target group comprised 11 mathematics teachers from a school located in Kaengkhro District, Chaiyaphum province, who were purposively selected because they were trained in the LS and OA workshop with the Center for Research in Mathematics Education (CRME), Faculty of Education, Khon Kaen University, Thailand. The research school offers secondary education from Grade 7 to 12 students. Only two Grade 7 mathematics teachers from 
the target group were selected as research participants to conduct the 10 cycles of research lessons.

The target group was not only involved in the pre-test and post-test at the first phase of this study but also involved in the three steps of LS. In the three steps of LS, the target group collaboratively planned the lesson plans, observed the lessons taught by the two research participants, and finally reflected what they observed and made the necessary improvements for the following lessons. Although the target group was purposively selected, the two research participants were involved on a voluntary basis. The two Grade 7 classes, namely M.1/2 and M.1/4 classes, had 27 and 40 students respectively, adding up to a total of 67 students involved in the 10 cycles of research lessons. Four researchers from the CRME participated as raters (R1 to R4) using the AssessToday rubric to evaluate the two research participants for 10 cycles of research lessons. The four raters were trained by the AssessToday rubric creator, who was one of the coresearchers for this project.

The target group was pre-tested before they were given LS and OA innovation training. After the training, the target group was then post-tested. Any significant difference in the pre-test and post-test findings could then be attributed to the LS and OA innovation training. However, because the research design was not purely experimental and there was no control group, this inference is uncertain, and may be the limitation of this study.

\section{Research Procedure, Instruments, and Data Collection}

Mathematics teachers' abilities in developing formative assessment were hypothesized to improve after the LS and OA innovations as a means to teach mathematics lessons. The research procedure consisted of three phases. In the first phase, the target group was pre-tested and post-tested on their understanding of formative assessment before and after LS and OA innovation training. The independent variables were their understanding of formative assessment, methods used in formative assessment and how they used the information from the formative assessment, while the dependent variables were the LS and OA innovations in the first phase. In the second phase, the target group was involved in LS innovation while the two research participants implemented 10 cycles of LS and OA innovations. 
The final phase was the post-stage of the two research participants' abilities in developing formative assessment after the 10 cycles of LS and OA innovations. The two research participants' abilities in developing formative assessment before the introduction LS and OA innovations were considered as independent variables, while the same abilities measured again in the post-stage after the LS and OA innovations were identified as dependent variables.

The research procedure employed three methods of data collection, namely lesson observation, an in-depth interview with the mathematics teachers, and the AssessToday rubric items recorded by the researchers. The mathematics teachers' formative assessment abilities were observed and recorded using the AssessToday rubric as an instrument while teaching two Grade 7 classes, which were identified as Class A and Class B in Phase 2. Briefly, the data collection was carried out in the following manner.

In Phase 1, all the mathematics teachers from the research school attended the LS and OA training for two days. The target group was trained on how to implement the LS, OA, and AssessToday components. After the workshop, the research participants and target group practiced what they had learned from the training in their classroom every week for the following 15 weeks. The training in LS, O, and the components of AssessToday practices was facilitated by the four raters who were researchers and research assistants.

This was followed by Phase 2, where a total of nine mathematics teachers who were from the target group in Phase 1 observed 10 research lessons to evaluate the two research participants' abilities in developing formative assessment. Each lesson lasted approximately 50 minutes to one hour. The four raters were involved in collecting data during the lesson observation using the AssessToday rubric, and took field notes, particularly episodes or phenomena that may be raised for further clarification and discussion during the in-depth interview.

All 10 lessons were video recorded. The video-recorded lessons also allowed the researchers to review each lesson several times, as well as to avoid missing some phenomena that might have been overlooked during the lesson observation. Immediately after each 
classroom observation, an in-depth interview was carried out with the participating mathematics teachers. The interview began with research participants reflecting on the lesson just taught. They were asked to highlight and elaborate any formative assessment activities that they had planned or practiced to show the seven components of AssessToday. Likewise, any significant phenomena that were observed by the researchers during the lesson would be brought up and discussed with the all the participating mathematics teachers, both research participants and the target group.

The research instruments utilized in this study consisted of 10 lesson plans for Grade 7 on the learning topic of algebra, field notes, the AssessToday rubric, classroom observation video recordings interview protocols and students' written work. The LS procedure was begun with collaborative lesson planning, followed by collaborative classroom teaching and observation, and ended with the collaborative reflection on the lesson. The AssessToday rubric comprised mathematics teachers' abilities in writing learning objectives, using quality questions, handling students' answers to diagnose problems and expand their learning, encouraging students to do self-assessment or check their mathematical thinking process, providing an active learning environment, adjusting teaching approach to assessment and having sufficient learning evidence.

Reliability considered in the AssessToday rubric involved rater reliability (Moskal \& Leydens, 2000). Rater reliability generally refers to the consistency of scores that are assigned by two independent raters (inter-rater reliability) and that are assigned by the same rater at different points in time (intra-rater reliability) (Reddy \& Andrade, 2010). Inter-rater reliability was employed to ensure the reliability of the AssessToday rubric as an instrument. The degree of agreement between the raters provided the degree of accuracy present in the ratings. If agreement among the raters was good, then there was a high possibility that the ratings did in fact reflect the component they were purported to reflect. The rubric helped raters to be more consistent when grading (Walser, 2011). However, the researchers made the final decision by relooking into the video recording if a discrepancy existed in the rating scores in AssessToday rubric. Table 2 shows the AssessToday rubric rated by the four raters in a pilot lesson. Inter-raters' rating result showed that there was no significant difference among their rating score. 
Table 2

Result of the Raters' Rating Scores in the Pilot Lesson

\begin{tabular}{lllll}
\hline $\begin{array}{l}\text { Formative assessment } \\
\text { component }\end{array}$ & Rater 1 & Rater 2 & Rater 3 & Rater 4 \\
\hline Learning target & Apprentice & Apprentice & Apprentice & Apprentice \\
Question quality & Apprentice & Apprentice & Apprentice & Apprentice \\
$\begin{array}{l}\text { Nature of } \\
\text { questioning }\end{array}$ & $\begin{array}{l}\text { Practi- } \\
\text { tioner }\end{array}$ & Practitioner & Practitioner & Practitioner \\
$\begin{array}{l}\text { Self-evaluation } \\
\text { Practi- } \\
\text { tioner }\end{array}$ & Practitioner & Practitioner & Practitioner \\
$\begin{array}{l}\text { Observation of } \\
\text { student affect }\end{array}$ & $\begin{array}{l}\text { Practi- } \\
\text { tioner }\end{array}$ & Practitioner & Practitioner & Practitioner \\
$\begin{array}{l}\text { Instructional } \\
\text { adjustment }\end{array}$ & Apprentice & Apprentice & Apprentice & Apprentice \\
$\begin{array}{l}\text { Evidence of } \\
\text { learning }\end{array}$ & $\begin{array}{l}\text { Practi- } \\
\text { tioner }\end{array}$ & Practitioner & Practitioner & Practitioner \\
\hline
\end{tabular}

\section{Data Analysis and Triangulation}

All the video recordings taken from the classroom observations and interviews were imported into NVivo and transcribed verbatim. The videos of lesson observations were coded for emerging themes, and then the nodes were explored to search for patterns and characteristics. Meanwhile, the interview transcripts were read several times to gain emerging themes. The themes were then categorized into related groups.

Data triangulation was employed in this study. The AssessToday data, field notes written during the lesson observations, interview transcripts, and the videos were systematically triangulated. Thematic analysis was used to analyze all the qualitative data except the AssessToday components. Thematic analysis was found to be suitable for this study because it is the process of identifying patterns or themes within qualitative data (Clarke \& Braun, 2013). A literary analysis was used to analyze the data collected from the AssessToday rubric. Literary analysis was used to create a textual 
analysis of the research lesson observations. For the most part, the researchers broke down the literary work into various components in order to develop a better understanding of the teachers' formative assessment abilities and their overall proficiency level.

\section{RESULTS}

The results of this study are presented in accordance with the research procedure indicated above. The initial results highlight the pre-test and post-test of target group in terms of their understanding of formative assessment before and after the LS and OA innovation training respectively. The final results revealed the impact of LS and $\mathrm{OA}$ innovations through the 10 research lessons on Grade 7 mathematics teachers' abilities in developing formative assessment.

\section{Pre-test and Post-test Results on Mathematics Teachers' Understanding about Formative Assessment}

Data was collected using a questionnaire as pre-test and post-test before and after the target group attended the LS and OA innovation training. Data was analysed using the emerging themes and those participants who fit into the themes was reported in percentage. Table 3 shows pre-test and post-test results regarding their understanding about formative assessment, the methods used in formative assessment, and how they could use the information or data from the formative assessment.

The above results show that the mathematics teachers in the target group have improved their conceptions of formative assessment drawn on students' understanding, adjustment of teaching and learning, concern with the learning target, students' affect and participation during instruction after they attended the LS and OA innovation training. In addition, their conception of the methods used in formative assessment changed from the test, mid-term and final examination, exercise and homework to questioning and discussion, observation on students' ideas and ways of thinking and gain of learning target. Furthermore, they focused on improvement for the next instruction, discussion to reach learning target, extension of students' understanding, adjustment of teaching immediately and improvement of the lesson plan more than before. 
Table 3

Result of the Pre-test and Post-test

\begin{tabular}{|c|c|c|}
\hline Content / Emerging Themes & Pre-test $(\%)$ & Post-test $(\%)$ \\
\hline \multicolumn{3}{|l|}{ What is formative assessment? } \\
\hline $\begin{array}{l}\text { Evaluation of learning achievement dur- } \\
\text { ing instruction }\end{array}$ & 18.18 & 27.27 \\
\hline $\begin{array}{l}\text { Exploration of students' understanding } \\
\text { during instruction }\end{array}$ & 54.55 & 72.73 \\
\hline $\begin{array}{l}\text { Examination of students' development } \\
\text { in reaching to learning target }\end{array}$ & 9.09 & 36.36 \\
\hline $\begin{array}{l}\text { Assess to realize the instructional prob- } \\
\text { lem during instruction }\end{array}$ & 9.09 & 9.09 \\
\hline $\begin{array}{l}\text { Take information to adjust teaching and } \\
\text { learning }\end{array}$ & 18.18 & 63.64 \\
\hline Observation on students' participation & 9.09 & 18.18 \\
\hline $\begin{array}{l}\text { Questioning and summarization in } \\
\text { problem-solving to reach learning target }\end{array}$ & 9.09 & 36.36 \\
\hline $\begin{array}{l}\text { Observation on the gain of learning } \\
\text { target }\end{array}$ & 0.00 & 36.36 \\
\hline \multicolumn{3}{|l|}{$\begin{array}{l}\text { What are the methods used in forma- } \\
\text { tive assessment in your classes? }\end{array}$} \\
\hline Test, mid-term and final examinations & 45.45 & 9.09 \\
\hline Exercise and homework & 90.91 & 27.27 \\
\hline Questioning and discussion & 45.45 & 72.73 \\
\hline Observation on students' behaviour & 72.73 & 72.73 \\
\hline $\begin{array}{l}\text { Observation on students' ideas and ways } \\
\text { of thinking }\end{array}$ & 18.18 & 63.64 \\
\hline $\begin{array}{l}\text { Observation on the gain of learning } \\
\text { target }\end{array}$ & 0.00 & 36.36 \\
\hline \multicolumn{3}{|l|}{$\begin{array}{l}\text { How could you use the information/ } \\
\text { data from formative assessment? }\end{array}$} \\
\hline $\begin{array}{l}\text { Exploration of students' understanding } \\
\text { and extension }\end{array}$ & 9.09 & 27.27 \\
\hline Improvement for next instruction & 36.36 & 63.64 \\
\hline $\begin{array}{l}\text { Examination of learning achievement at } \\
\text { the end of semester }\end{array}$ & 45.45 & 9.09 \\
\hline Adjustment of teaching immediately & 9.09 & 27.27 \\
\hline Tutorial teaching & 9.09 & 0.00 \\
\hline Improvement of lesson plan & 0.00 & 27.27 \\
\hline Discussion to reach to learning target & 0.00 & 45.45 \\
\hline
\end{tabular}




\section{Impact of LS and OA on Mathematics Teachers' Abilities in Developing Formative Assessment}

There were 10 research lessons conducted by the research participants (Teacher A and Teacher B) in the two respective Grade 7 classes (Class A and Class B). The four raters used field notes and AssessToday to evaluate the research participants' abilities in developing formative assessment. If there was any discrepancy in terms of the AssessToday rubric rating among the raters, the researchers would make the final decision by referring to video recording. Table 4 shows the final ability level of the two research participants for 10 cycles of LS and OA teaching, rated by the four raters.

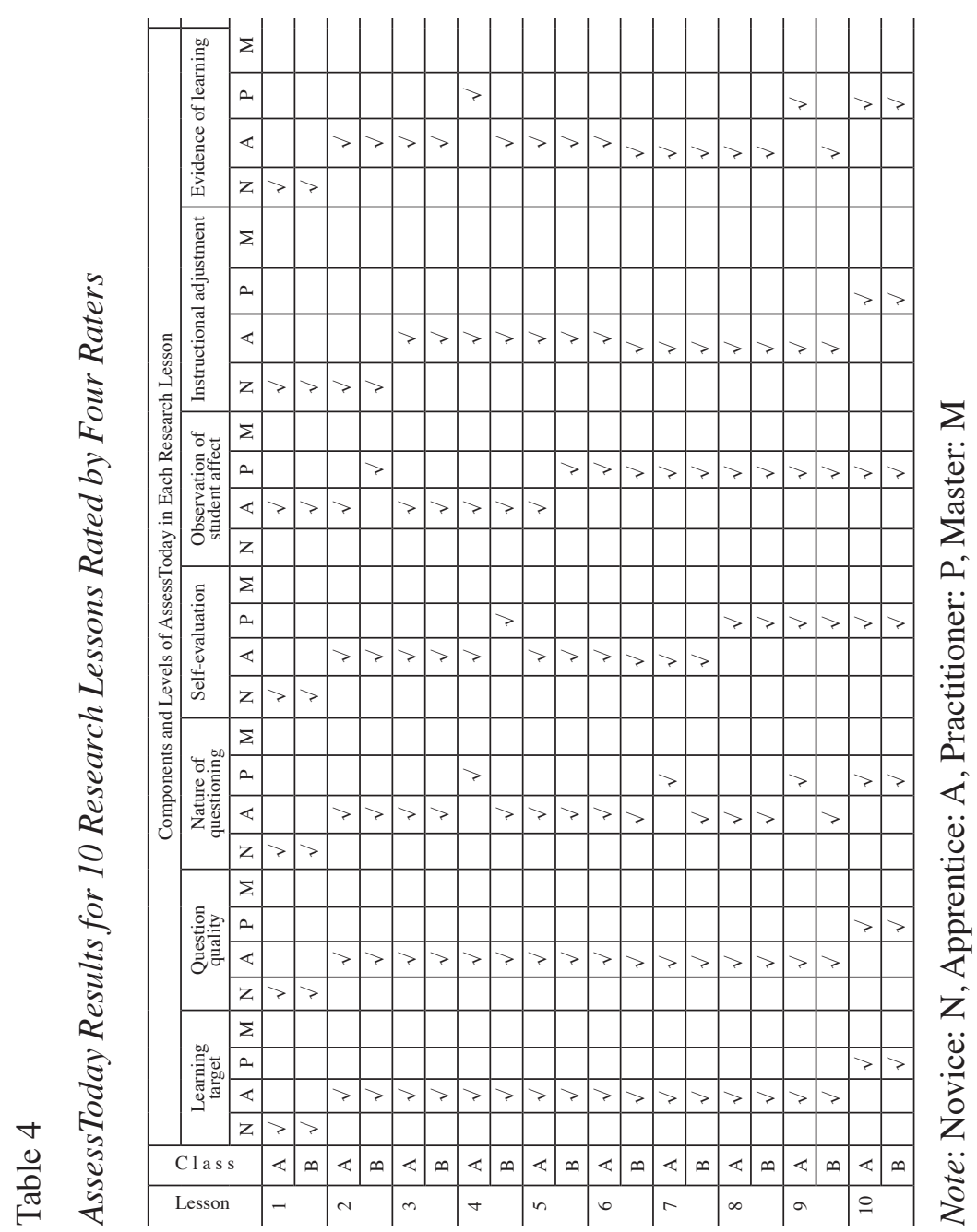


The results from the AssessToday rubric show that both research participants were progressing gradually from novice level to practitioner level in their abilities to develop formative assessment. Both mathematics teachers showed their formative assessment abilities to be at apprentice level in writing learning targets, using quality questions, observation of student affect and instructional adjustment components. In addition, the Class A mathematics teacher performed better in questioning and evidence of learning, while the Class B mathematics teacher was better in the self-evaluation and observation of student affect components.

These results revealed that both research participants used a traditional teaching approach at the beginning. For example, they did not write the learning target or explain the contents verbally. This implies that both research participants were at novice level during Lesson 1 according to the indicators of the AssessToday rubric (refer to Table 1). However, they seemed to improve from Lesson 2 onwards. This was apparent in Lesson 2, where both research participants improved in writing learning targets, as shown in Figure 2.

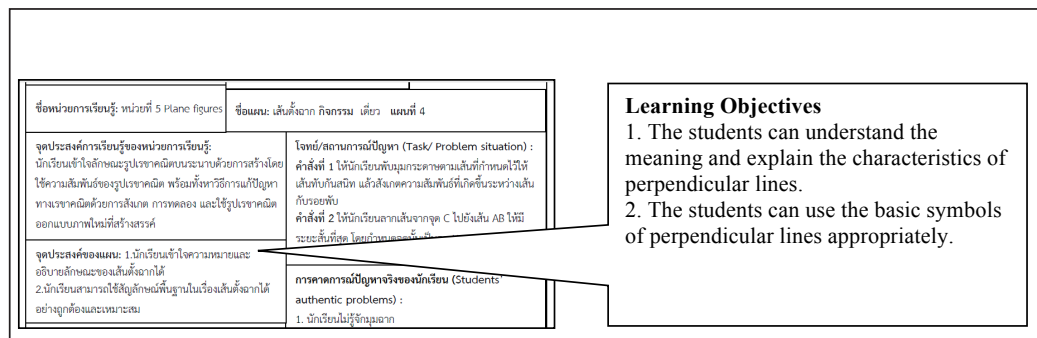

Figure 2. Learning targets in Lesson 2

Furthermore, the above result was triangulated with classroom observation field notes, and it was found that the teachers walked around the classroom to observe and take notes about students' ideas. They collected students' ideas and took them into consideration during reflection sessions by comparing the students' ideas with the designed learning targets. Figure 3 illustrates the classroom observation of Lesson 2.

The field notes in Lesson 2 below show that Teacher A and Teacher $\mathrm{B}$ had improved from novice to apprentice level in the learning target component. 
“Teacher A compare students' ideas with learning target." (Rater 2's field notes)

"Teacher A provide discussion and comparison of students' ideas relate to learning target." (Rater 4's field notes)

"Teacher B determine learning target in lesson plan. She tries to involve students in solving problem, discussion on idea, but does not conclude to learning target." (Rater l's field notes)

"Teacher B discuss and compare students' ideas." (Rater 3's field notes)

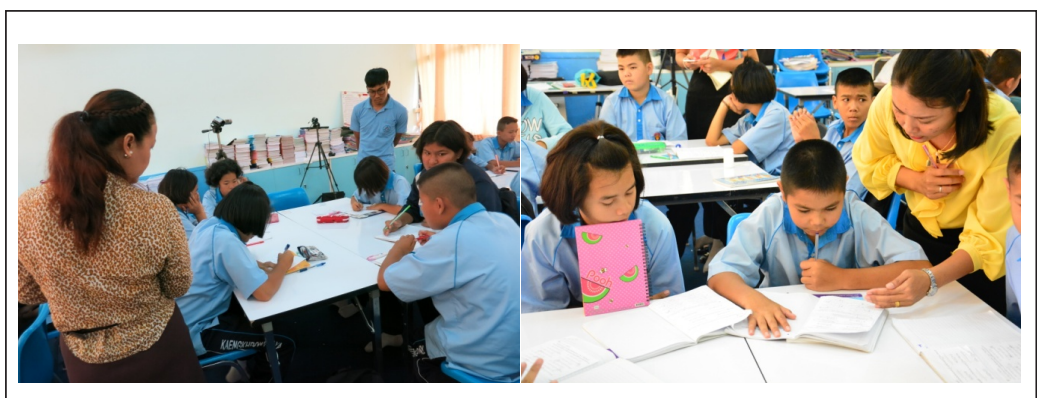

Figure 3. Classroom observation of Lesson 2 Class A and B

The AssessToday results were triangulated with the classroom observations and in-depth interviews. Both research participants had progressed from novice to apprentice level in terms of their abilities in writing learning objectives. For example, Teacher A and Teacher B's verbatim interview data during the reflection step of LS revealed that:

"Some students explain the meaning and characteristics of perpendicular lines by using folding trace in the paper. They write the new line for construction of the perpendicular line. This shows that they can understand the learning target." (Teacher A)

"Some students had difficulty in using the basic symbol to represent the perpendicular lines. I can know whether my students can do whatever that I set for learning target or not." (Teacher B) 
Although both research participants wrote the learning targets by comparing students' ideas with the designed learning targets, they did not discuss the students' ideas and students did not write the lesson conclusion. This suggested that both research participants' abilities in developing formative assessment were at the apprentice level. Observation results in regards to the collaboration in preparing a lesson plan, as the first step of the LS procedure, revealed that the target group collaboratively determined the mathematics equation as $(+7)-(+8)+(-5)-(-9)$ as well as decided the learning targets, as shown in Figure 4.

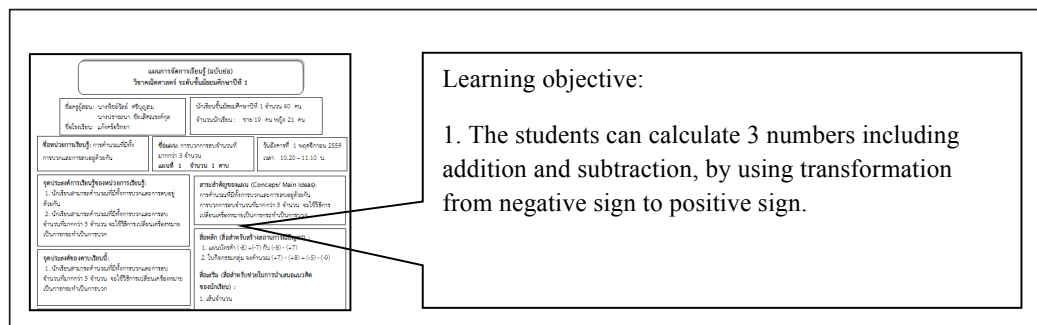

Figure 4. Collaboration in writing learning targets

The results from the AssessToday rubric indicate that both research participants improved gradually from apprentice level to practitioner level starting from research lesson 6 onwards, in all seven components of formative assessment. However, both research participants improved slower in writing learning targets, using quality questions and instructional adjustment, compared with other components. Nevertheless, they successfully gained sufficient ability in developing formative assessment and were able to play the role of practitioner in the observation of the student affect component.

The AssessToday results were triangulated with the classroom observations and in-depth interviews. Both teachers showed substantial improvement in research lesson 10 from apprentice level to practitioner level for all seven components of formative assessment. The outcomes of the classroom observation (see Figure 5) further supported the AssessToday results. For instance, the mathematics teachers were able to compare students' idea acquisition with the designated learning target. 


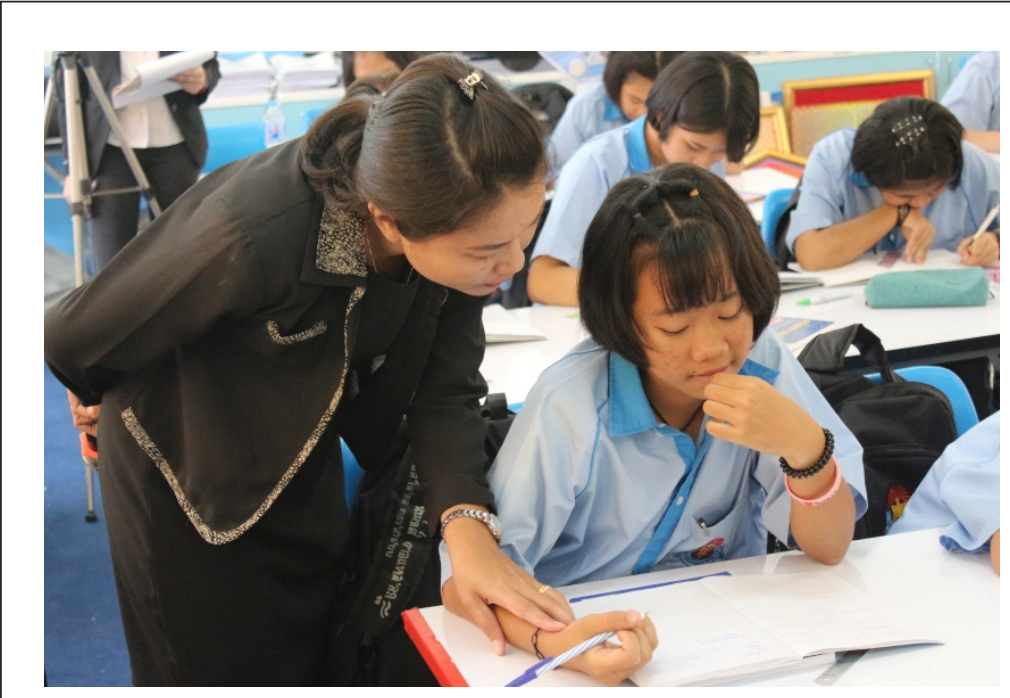

Figure 5. Classroom observation in Lesson 10

In addition, Teacher A and Teacher B's verbatim interview data during the reflection step of LS after Lesson 10 revealed that:

"The students performed the addition by grouping. They calculated the first group correctly, $[(+7)-(+8)]$ by changing the minus sign to the plus sign; however, they made the errors in the second group by performing the calculation the same way [(-5) - (-9)], and as a result produced errors as what we expected. This implies that teacher leads the discussion all the ideas until learning target are achieved." (Teacher A)

"Some students can calculate $(+7)-(+8)$ by getting the answer as -1 and calculate (-5) - (-9) by getting the answer 4 and then bring together for getting +3 . This shows that I make the interconnections all the ideas learned until the learning targets are reached." (Teacher B)

Based on the classroom observation results, both research participants utilized the four steps of OA while they implemented the 10 cycles of research lessons, namely posing open-ended problems, students' self-learning, whole class discussion and comparison, and summing 
up by connecting students' emergent mathematical ideas. However, they did not discuss or correlate all the ideas to work toward achieving the learning objectives from Lesson 6 to Lesson 9. As a result, both research participants stayed at apprentice level for 4 continuous lessons. They started to learn how to lead the discussion, summarize, and interconnect all the ideas to achieve the learning objective, abilities that were only detected in Lesson 10. For example, the students found solutions and summarized what they had learned to meet the designated learning objective, as shown in the students' written work in Figure 6.

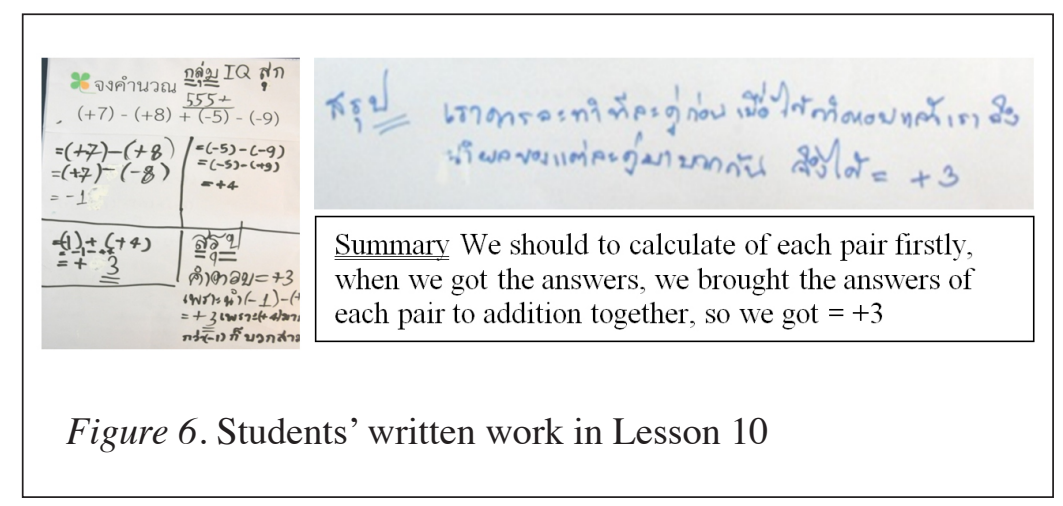

\section{DISCUSSION AND CONCLUSION}

The researchers explored the impact of LS and OA training on enhancing mathematics teachers' formative assessment abilities using the AssessToday rubric. The results of this study contribute to our recognition of the importance of LS and OA practices while teaching mathematics in enhancing mathematics teachers' formative assessment abilities, such as writing learning targets, using quality questions, nature of questioning, self-evaluation, observation of student affect, instructional adjustment and evidence of learning. The results also show that there were some slight and gradual changes in their formative assessment abilities at the later cycles of the research lessons. These imply that the participating teachers progressed from novice level to practitioner level in teaching algebraic reasoning after training in LS and OA. The findings can be rationalized in terms of the current evidence and should be applied to improve mathematics teachers' formative assessment abilities in the future. 
Moreover, the results indicate that formative assessment is a proven strategy for improving student achievement and that AssessToday is an effective tool in assisting mathematics teachers to reach their fullest potential. In addition, the results of this study are consistent with related empirical literature. Petchara and Thinwiangthong (2016) found that the utilization of LS and OA could enhance students' motivation, as well as learning objectives, students' selfassessment and teachers' strategic questions. This was reflected in the improvements in the mathematics teachers' formative assessment abilities. Srikuta and Thinwiangthong (2014) discovered that LS and OA could promote better formative assessment planning, while Chaona and Inprasitha (2013) emphasized that LS and OA could support teachers in assessing students' learning. The study further reinforces Black and William's (1998) argument that standards of formative assessment can be raised only by changes that are put into direct effect by teachers and students in the classroom. Thus, formative assessment is a vital component in students' learning development and can be a body of firm evidence to raise standards of achievement (Black \& William, 1998).

The study findings suggest that mathematics teachers should be encouraged to use LS and OA as a method to enhance their formative assessment abilities. However, it requires a meticulous understanding of details of LS (Inprasitha, 2011) and OA (Nohda, 2000) concepts, as well as the related theories of formative assessment (Eddy \& Harrell, 2013) and action-taking in the classroom context while implementing LS and OA. On top of that, it has been proven that formative assessment is able to improve the quality of education in the classroom. The AssessToday rubric was developed to inform mathematics teachers about their use of formative assessment and thus provides a framework for improvement. The development and subsequent validation of the AssessToday rubric will provide an excellent tool to assist teachers in developing formative assessment in the mathematics classroom. Further studies can then be conducted to explore the methods of utilizing LS and OA in resolving classroom management problems and encouraging effective teaching approaches.

The Thailand Ministry of Education has improved the quality of basic education over the past two and a half decades (Lathapipat \& Sondergaard, 2015). Although there may be several strategies that 
are able to realize this goal, formative assessment is a proven method that can increase achievement, motivation and quality of education when used appropriately (Heitz, 2013). Additionally, the results of this study have confirmed that the AssessToday rubric is able to inform mathematics teachers about their formative assessment use, and thus provides a framework for improvement (Eddy, Harrell, \& Heitz, 2017). Since the creators of the AssessToday rubric did not design it as an evaluation tool to be used as judgments on teachers, it is identified as an informative tool to assist mathematics teachers in their personal development (Eddy \& Harrell, 2013). Based on this line of reasoning, the researchers hope that the AssessToday rubric will be utilized for this purpose by all teachers and professional learning communities in Thailand.

\section{ACKNOWLEDGEMENT}

This work was supported by the Centre of Excellence in Mathematics, CHE Si Ayutthaya Road, Bangkok 10400, Thailand (Development of Teachers' Formative Assessment by Using Lesson Study and Open Approach: Budget Year 2016 to 2018).

\section{REFERENCES}

Andrade, H. L. (2010). Students as the definite source of culminating demonstrations of mastery. In G. L. Cizek and H. L. Andrade (Eds.), Handbook of formative assessment (pp. 90-105). New York, NY: Routledge.

Becker, J.P., \& Shimada, S. (1997). The open-ended approach: A new proposal for teaching mathematics. Reston, Virginia: National Council of Teachers of Mathematics.

Bell, B., \& Cowie, B. (2001). The characteristic of formative assessment in science education. Science Education, 85(5), 536-553.

Black, P., Harrison, C., Lee, C., Marshall, B., \& William D. (2004). Working inside the blackbox: Assessment for learning in the classroom. Phi Delta Kappa, September, 9-21.

Black, P., \& William, D. (1998). Inside the black box: Raising standards through classroom assessment. Phi Delta Kappa, September, 1-13. 
Black, P., \& William, D. (2009). Developing the theory of formative assessment. Educational Assessment, Evaluation \& Accountability, 21(1), 5-31. doi: 10.1007/s11092-008-9068-5

Bloom, B.S. (1984). The 2 sigma problem: The search for methods of group instruction as effective as one-to-one tutoring. Educational Researcher, 13(6), 4-16.

Brookhart, S., Moss, C., \& Long, B. (2008). Formative assessment that empowers. Educational Leadership, 66(3), 52.

Centre for Educational Research and Innovation. (2008). Assessment for learning - The case for formative assessment. Paper presented at OECD/CERI International Conference Learning in the 21 $1^{\text {st }}$ century: Research, innovation and policy, Paris, France, 15-16 May.

Chaona, S., \& Inprasitha, M. (2013). Teacher's assessment for students' learning in classroom using lesson study and open approach. Psychology, 4(12), 1069-1072.

Chin, C. (2006). Classroom interaction in science: Teacher questioning and feedback to students' responses. International Journal of Science Education, 28(11), 1315-1346.

Cizek, G.J. (2001). More unintended consequences of high-stakes testing. Educational Measurement: Issues and Practice, 20(4), 19-27.

Clarke, V., \& Braun, V. (2013) Teaching thematic analysis: Overcoming challenges and developing strategies for effective learning. The Psychologist, 26(2), 120-123.

Eddy, C.M., \& Harrell, P.E. (2013). AssessToday: A short-cycle formative assessment observation protocol. University of North Texas.

Eddy, C.M., Harrell,P.E., \& Heitz,L. (2017).An observation protocol of short-cycle formative assessment in the mathematics classroom. Investigation in Mathematics Learning, 9(3), 130147. doi: 10.1080/19477503.2017.1308699

Eddy, C.M., \& Inprasitha, M. (2012). US-Thailand research network to advance the teaching and learning of algebraic reasoning research proposal. Khon Kaen, Thailand: Khon Kaen University.

Fernandez, C., Cannon, J., \& Chokshi, S. (2003). A.U.S.-Japan lesson study collaboration reveals critical lenses for examining practice. Teaching and Teacher Education, 19, 171-185.

Gallagher, C.W. (2010). Keeping the focus, expanding the vision, maintaining the balance: Preserving and enhancing formative 
assessment in Nebraska. In G.L. Cizek and H.L. Andrade (Eds.), Handbook of formative assessment (pp. 328-343). New York, NY: Routledge.

Harlen, W. (2007). Formative classroom assessment in science and mathematics. In J. H. McMillan (Ed.), Formative classroom assessment (pp. 116-135). New York, NY: Teachers College Press.

Hart, L.C., Alston, A.S., \& Murata, A. (Eds.). Lesson study research and practice in mathematics education. London, UK: Springer Science + Business Media. doi: 10.1007/9718-90-481-99419-14

Heitz, L. (2013). The validation of a short-cycle formative assessment observation protocol for science and mathematics instruction (Unpublished doctoral dissertation). University of North Texas, USA. Retrieved from https://digital.library.unt. edu/ark:/67531/metadc407820/

Heritage, M. (2007). Formative assessment: What do teachers need to know and do? Phi Delta Kappan, 89, 140-145.

Heritage, M. (2010). Formative assessment: Making it happen in the classroom. Thousand Oaks, CA: Corwin.

Guskey, T.R.(2007). Closing achievement gaps: Revisiting Benjamin S. Bloom's learning for mastery. Journal of Advanced Academics, 19(1), 8-31.

Inprasitha, M. (2011). One feature of adaptive lesson study in Thailand: Designing a learning unit. Journal of Science and Mathematics Education in Southeast Asia, 34(1), 47-66.

Kaur, A., Awang Hashim, R., \& Noman, M. (2014). Teacher autonomy support: Does it hinder motivation among Thai students? Malaysian Journal of Learning and Instruction, 11, 171-189.

Korkmaz, I. (2009). The examination of elementary teachers' effectiveness of using questioning strategies in their classroom. International Journal of Learning, 16(6), 513-522.

Lathapipat, D., \& Sondergaard, L.M. (2015). Thailand - wanted: A quality education for all (English). Washington, DC: World Bank Group.

Leahy, S., Lyon, C., Thompson, M., \& William,D. (2005).Classroom assessment minute-by-minute, day-by-day. Educational Leadership, 63(3), 18-24.

Lewis, C. (2002). Lesson study: A handbook of teacher-led instructional change. Philadelphia, PA: Research for Better Schools. 
Meyer, R.D., \& Wilkerson, T.L. (2011). Lesson study: The impact on teachers' knowledge for teaching mathematics. In L.C. Hart, A.S. Alston, \& A. Murata (Eds.), Lesson study research and practice in mathematics education (pp.15-26). London, UK: Springer Science + Business Media. doi: 10.1007/971890-481-9941-9-14

Moskal, B.M., \& Leydens, J.A. (2000). Scoring rubric development: Validity and reliability. Practical Assessment, Research \& Evaluation, 7(10).

Nohda, N. (2000). Teaching by open-approach method in Japanese mathematics classroom. Proceedings of the Conference of the International Group for the Psychology of Mathematics Education (PME), Hiroshima, Japan, July 23-27, Volume 1, ERIC ED 466736.

Petchara, S., \& Thinwiangthong, S. (2016). Formative assessment to support students' motivation in mathematics classroom using lesson study and open approach. KKU Research Journal HS, 4(2), 78-91. [in Thai]

Popham, W.J. (2008). Transformative assessment. Alexandria, VA: Association for Supervision and Curriculum Development.

Reddy, Y. \& Andrade, H. (2010). A review of rubric use in higher education. Assessment \& Evaluation in Higher Education, 35, 435-448. doi: 10.1080102602930902862859

Sambová, L., \& Tichá, M. (2016). On the way to develop open approach to mathematics in future primary school teachers. ERIES Journal, 9(2), 37-44.

Shepard, L.A. (2000). The role of assessment in a learning culture. Educational Researcher, 29(7), 4-14.

Shute,V.J.(2008).Focusonformativefeedback.ReviewofEducational Research, 78(1), 153-189. doi: 10.3102/0034654307313795

Srikoon, S., Bunterm, T., Nethanomsak, T., \& Tang, K.N. (2017). A comparative study of the effects of the neurocognitivebased model and the conventional model on learner attention, working memory and mood. Malaysian Journal of Learning and Instruction, 14(1), 83-110.

Srikuta, S., \& Thinwiangthong, S. (2014). Teachers' use of formative assessment in classroom using lesson study and open approach. Proceedings of the $7^{\text {th }}$ International Conference on Educational Research (ICER), Khon Kaen, Thailand, September 13-14.

Stiggins, R. (2010). Essential formative assessment competencies for teachers and school leaders. In G. L. Cizek and H. L. 
Andrade (Eds.), Handbook of formative assessment. (pp. 233250). New York, NY: Routledge.

Tachibana, H. (2007). Teaching and assessment based on teaching guides. In M. Isoda, M. Stephens, Y. Ohara, T. Miyakawa (Eds.), Japanese lesson study in mathematics: Its impact, diversity and potential for educational improvement (pp. 2-7). Singapore: World Scientific Publishing.

Tall, D. (2008). Using Japanese lesson study in teaching mathematics. The Scottish Mathematical Council Journal, 38, 45-50.

Tan, S.F., Lim, C.S., \& Chew, C.M. (2017). Changes in teachers' reflection after lesson study process. Malaysian Journal of Learning and Instruction, Special Issue, 145-172.

Thailand Ministry of Education. (2008). Core curriculum for basic education 2008. Bangkok, Thailand: The Agricultural Cooperation Federation of Thailand. [in Thai]

Thinwiangthong, S., Suttiamporn, W., Pattanajak, A., \& Inprasitha, M. (2017). AssessToday in classroom using lesson study and open approach. Paper presented at the $3^{\text {rd }}$ Conference of Thailand Society Mathematics Education, Chiang Mai, Thailand, March 10-12. [in Thai]

Veldhuis, M. (2015). Improving classroom assessment in primary mathematics education. Utrecht: Freudenthal Institute for Science and Mathematics Education, Faculty of Science, Utrecht University / FIsme Scientific Library.

Walser, T. (2011). Using a standard rubric to promote high standards, fairness, student motivation and assessment for learning. MountainRise, 6(3), 1-13.

William, D. (2010). An integrative summary of the research literature and implications for a new theory of formative assessment. In G. L. Cizek and H. L. Andrade (Eds.), Handbook of formative assessment (pp. 18-40). New York, NY: Routledge. 